\title{
GRASSING OF PUMICE LAND
}

By P. W. SMALLFIELD, Director, Extension Division, Department of Agriculture, Wellington.

From quite early days in the colonization of New Zealand farmers began to search for satisfactory methods of grassing and farming the great areas of light volcanic soils in the central region of the North Island. Even the earliest land-improvers seemed to think that these pumice soils were suitable for pastoral purposes, but for many decades their hopes, engendered by the excellent red clover growth in the initial pasture sowings, fell as the pasture swards ran out and sheep and cattle pined from bush-sickness. This initial excellence of red clover was certainly a factor which kept people perpetually interested in the land, for although the land is easily cultivated, the virgin pumice soils appear infertile and unattractive. This. aspect was commented on as early as 1839 by J. C. Bidwell, who, in recording his travels from Tauranga to Taupo, remarked "... the land is not bad ... I have seen clover and grass growing in the garden of a Mission or I might perhaps have thought the land was worse than it is ..." It was the intuition that really intensive farming was ultimately possible on these pumice lands that kept invigorated the faith of such men as Aston, Clifton, Carr Rollett, and Earle Vaile in their work of seeking methods which would overcome the problem of pumice land farming.

The great open tussock plains of the Central Plateau attracted attention in the 50's and 60's as a field for extensive pastoral farming; but except in the southern area where the surface soil has been sprinkled with Ngauruhoe ash or in isolated areas where greywacke fans spread over the pumice flats sheep farming failed because of bush-sickness, which affected stock in the areas of the two major ash showers, Taupo and Kaharoa. But even in the areas where bush-sickness did not prevent sheep farming the poor grazing afforded by the tussock pastures and the deterioration caused by fires and rabbits steadily decreased the importance of the area for sheep farming.

In the 70's and 80's farming pushed up toward the central region from the Bay of Plenty and the 
Waikato to meet in both areas with the. problems of bush-sickness and pasture establishment. The depression in the 80's and the counter-attraction. of bushland for -pastoral purposes (the bush-sick -forested lands at Mamaku were opened up in the 90's) delayed much further attention being paid to the open pumice lands until the early 1900 's, when phosphatic fertilizers became more freely used. Settlers could farm bush-sick areas only from a base that was free from the trouble, and the main bases for attack were the safe areas in the Tirua Matamata areas, the coastal swamps of the Bay of Plenty, and the lake and river bottoms. of Rotorua and the Upper Waikato. At this stage, after failure to secure permanence with perennial ryegrass, emphasis was placed on low fertility demanding grasses for permanent swards. Clifton, after experimenting in the Tirau-Tokeroa area, was a strong advocate of chewings fescue, while farmers in the Bay of Plenty, working from the coastal swamps on to the adjacent hills, were making do with Poa pratensis, Indian doub, and ratstail. But all these land-improvers felt that something much better was possible; they hoped that after a period in low fertility demanding grasses the soil would improve and that pastures of perennial ryegrass and white clover might be possible eventually. The Department of Agriculture in 1912, after experimenting with pasture plants at Rotorua and Lichfield, suggested that the following mixture might be suitable for permanent sowings on open pumice country :-

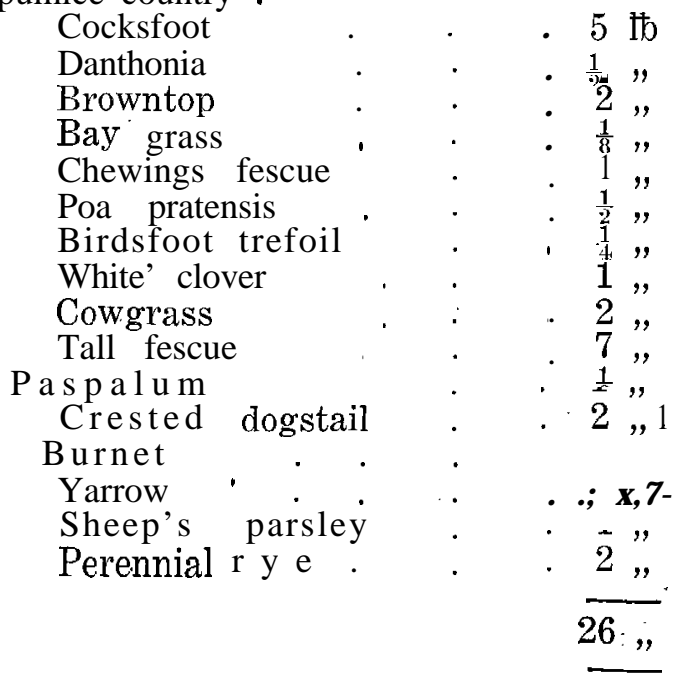


Commenting on the mixture Bayliss stated, "The use of stoloniferous grasses is a factor in the solution of this much-discussed problem. These grasses form a mat which completely hides the soil from sight. Such areas are extended by the creeping roots of the grasses in question as well as by the shed seed. The sod when ploughed up leaves an infinity of decaying vegetable, matter. so necessary to the increase of fertility in these soils. The soil is thus converted into one totally distinct from the original type to which. it belonged when sown down, and is started upon the upgrade, thus fitting it, in the course of years, for the production both of crops and varieties of grasses which could not possibly be raised upon it when it was first taken in hand." The Department suggested sowing the mixture with $1 \mathrm{cwt}$. of superphosphate and considered it gave better results than the common type of grass mixture composed of perennial ryegrass, cocksfoot, and red and white clovers. By 1920 Yorkshire fog was commonly included in mixtures and Vaile \& Butcher recommended the following for permanent pastures :-

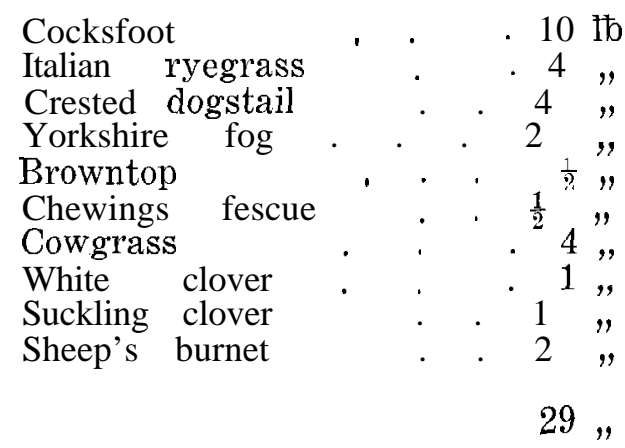

Butcher and Vaile commenting on the mixture stated, "The main consideration in grassing is getting a soil covering. Bare spaces are fatal; therefore, grasses that will grow should be sown. Cocksfoot gives the, most feed, except in winter, when frosts cut it rather badly. Perennial ryegrass is not perennial if one may express it that way. Italian rye is useful for quite a bit while other grasses come on. Crested dogstail forms a good sward. Danthonia . . . forms a dense sole absolutely permanent and keeps green throughout the winter. . . . Browntop gives a good pasture in spring and autumn, but yields no 
feed during frosts and drought. It, more than any other grass, tends to creep into and fill up all bare spaces,- although inclined to get root bound. Yorkshire fog is a grass too much neglected. It grows anywhere and gives a great bulk of feed, even if it be of rather poor quality. More than any other grass it adds humus to the soil and -it gives place to better grasses without. much trouble. Among the clovers cowgrass is supreme, yielding an immense quantity of rich feed on all pumice soils. On its cost it pays far better than any other pasture plant. White clover also thrives astonishingly and once established never leaves the, soil. ...,"

With bush-sickness the chief, retarding factor in pumice land development, large areas had been devoted- to forest plantings in the early 1900's, and with the, exotic forest boom in the 1920's there began a controversy over the opposing claims of forestry and farming for pumice lands. The pumice land enthusiasts, led by Vaile and Carr Rollett, claimed immense farming possibilities, "But," said the critics, "the land is bush-sick ; your pastures consist of inferior grasses. such as browntop, danthonia, and Yorkshire fog, and the land' would be best used for forestry.!' After presentation of the report of the Parliamentary Committee on the Rotorua-Taupo Railway, the State decided to take a hand in the grassing of pumice land; and the Department of Agriculture commenced work on 1,000 acres at Ngakuru in 1930. The decision for the technique of grassing was an important one ; on the one hand there was the general experience of the non-permanence of perennial ryegrass, at least in the initial sowings, and on the other hand there was the need for permanent and reasonably productive pasture 'if large areas were to be grassed. Fortunately Levy had sorted out the strains of New Zealand ryegrass and Certified perennial ryegrass had just come on the market. The question to be decided was whether Certified perennial ryegrass would be permanent from initial sowings .on pumice land if white clover growth could be stimulated sufficiently with phosphatic fertilisers. Instead. of building up fertility through a series of temporary pastures, the pasture itself was made to build up a veneer of fertility. Thus a relatively cheap and successful method of grassing was obtained and the practices initiated at Ngakuru are now used fairly generally for the grassing of many classes of ploughable scrub land. 


\section{PUMICE. SOILS}

The pumice soils derived from the various ash showers vary in texture and moisture-holding "capacity. The sandy silts from the Taupo and Mamaku showers; the sandy loams from Rotomahana mud, and the medium sands of the Kaharoa shower hold moisture fairly well and are capable of carrying permanent swards of perennial ryegrass and white, clover with topdressing. The soils derived from the Kaharoa shower, however, vary considerably in texture; at Galatea they are medium sands with a gravelly sand subsoil which causes the soil to dry out badly in summer, whilst at Kaharoa itself the surface soils are gravelly sands, and it is only toward the coast of the Bay of Plenty that the Kaharoa shower gives medium sands which are comparable for development with the sandy silts of the Taupo showers, The Tarawera gravel, from the Tarawera shower, is summer dry like the Kaharoa shower. In the river and stream valleys in the central. area covered by the Taupo shower the recent terraces consist of water-sorted material and the soils contain varying quantities of pumice stone pebbles ; where the pebbles are very thick fertility building under permanent pasture is not as rapid as on the sandy silts deposited from the. air.

In their natural state the open pumice lands appear particularly barren and unattractive. The surface vegetation consists of a tangled mass of manuka and manoao with, open spaces covered in tussock and with bracken fern and tutu covering the larger hills rising from the flats. Here are two views of pumice land fertility given by men who developed large areas :-

Vaile and Butcher stated: "Pumice soil is kindly stuff, never sodden, never baked-it may be worked every day of the year. It handles soft and velvety, is very warm, and forms a perfect seed-bed. Pumice land may be fairly termed natural grass country." On the other hand J. B. Campbell commented: "The land will do nothing itself. It differs from other land in that it is only the medium by which the human factor and capital can produce revenue, whereas in the case of most other classes of land the land is the main factor and the man and capital are the medium. Whatever it turns out to be is in exact proportion to what is put into it. The land itself is 
-not an asset: it is in fact a liability. Owing to the varying nature of pumice land its development up to a revenue-producing pitch is not a clear-cut job, It is a process. in which time plays the largest part; the poorer the land the longer it takes. The more it costs 'the less revenue it produces and the quicker it depreciates if neglected. When once started the work must be finished if a -man is to get his money or a portion of his money back. To half do the job is no better than to leave it untouched."

Taken together these views summarise pumice land: it is easily cultivated.; grass and clover seeds strike readily, but- the plants are not permanent unless really permanent strains are sown, and the land heavily phosphated and efficiently grazed so that the pastures may quickly build a veneer of fertile topsoil. "To half do the job is no better than to leave it untouched."

\section{CLIMATE}

The inland pumice areas receive. a rainfall of about 50 inches per annum. Frosts are common on the elevated inland areas and may occur at any time of the year. On the open pumice plains cold winter winds add to the severity of the climate. Shelter plantations are essential in dairy farm development; unseasonable, frosts sometimes hinder pasture establishment, killing the germinating clovers. October is usually the best month for spring sowing of grass and late-February for autumn sowing.

\section{GRASSING OF PUMICE LAND}

Before cultivation can be started the tangled mass of manuka and manoao scrub requires clearing and burning. Farmers in the past usually burnt the standing scrub several years ahead 'of development and simply knocked down the rotten sticks with a bar or harrows before ploughing, but because of the fire danger to exotic forests indiscriminate burning is now prohibited in many areas. In large-scale land development operations hand and machine cutting of scrub have now been replaced by crushing with a heavy flanged roller which breaks and cuts the scrub and gives results similar -to those from hand cutting.

For a long time there was a division of opinion. regarding the best method of cultivating pumice -land 
for grass. Some people advocated discing the surface, others ploughing, but both sides insisted on the need for a well-consolidated seed-bed. The discing advocates claimed that surface working retained the natural soil consolidation and preserved the thin layer of topsoil, while the ploughing advocates insisted that ploughing is necessary to eradicate tussock and manuka. The land-improver should aim to secure a fine, firm and moist seed-bed at the time of year suitable for the establishment of grasses and clovers. Accordingly he should plough all land that can be ploughed and rolled to a firm seed-bed, surface cultivate. with the discs and harrows all land too steep to roll, and use cattle to crush and cultivate the land too steep for implements. Thus he may prepare the land for sowing from. the flats to the hilltops. Experienca has shown that the most suitable cultivation on level and undulating land preparatory to grass is to plough with a lea mouldboard plough about 5 inches deep; leave fallow for 2 to 4 months to allow the furrow slices to close together; then roll on the furrow with the Cambridge roller; double disc and chain harrow to level the surface; roll before sowing seed and fertiliser ; and cover the seed with chain harrows and finally roll.

\section{PERMANENT PASTURES}

As mentioned previously pumice soils vary in moisture-holding capacity and their ability to hold white clover. The sandy silts from the Taupo and Mamaku showers, the sandy loams from Rotomahana mud, the Te Arero sands of valley faces, and the medium sands of the Kaharoa shower hold moisture fairly well and are capable of carrying swards of perennial ryegrass and white clover. with topdressing. On the other hand the gravelly sands of, the Kaharoa and Tarawera showers dry out badly in summer and will not hold permanent white clover. On these soils reliance must be placed on subterranean clovercocksfoot pastures. which are leniently summer grazed and supplemented with lucerne for summer grazing.

Experience in grassing pumice country has shown that provided triuly perennial strains of ryegrass and white clover are sown on suitable soils and the pastures regularly topdressed with superphosphate, quite good ryegrass-cocksfoot-white clover pastures can be estab- 
lished after the first ploughing. Establishment is somewhat slow and it is usually twelve "months before a close ryegrass-white clover sward is obtained. Slow ryegrass establishment is due to lack of nitrogen and a useful ryegrass growth is not obtained until the white clover growth encouraged by topdressing with superphosphate has covered the bare ground between the grass plants. The use of nitrogenous fertilizers to encourage quick ryegrass growth has not so far proved economical. Permanent pastures following temporary pastures of red clover establish more quickly'than those sown after the first ploughing. Whether permanent pastures should be sown after the first ploughing or after temporary pastures will depend on circumstances. When laying down large areas the sowing after the first ploughing appears to be most economical, while for a farmer gradually developing his farm the taking of initial crops of red clover and turnips followed by permanent grass is probably the best course to pursue. The time and cost of growing temporary pastures and the 'value of the fodder produced must be balanced against the cost of 5 to $6 \mathrm{cwt}$. of extra superphosphate necessary for permanent pastures sown after the first ploughing.

The basis of a permanent pasture mixture for easily ploughable pumice land suitable for white clover should consist of Certified perennial ryegrass $25 \mathrm{lb}$, cocksfoot $10 \mathrm{lb}$, and white clover $2 \mathrm{tb}$ per acre. For autumn sowings $5 \mathrm{lb}$ of Italian ryegrass or $5 \mathrm{tb}$ of short rotation ryegrass may be added and where red. clover (either cowgrass or Montgomery) is desired in permanent sowings 2 th should be included.

Red clover grows luxuriantly on- pumice land. The great danger from heavy sowings of red clover in permanent pasture mixtures is that its luxuriant growth may smother out the ryegrass and white clover plants. The red clover growth must be controlled either by cutting for silage or heavy stocking. Experience has shown that good permanent pastures can be obtained without the use of red clover, and for ease of pasture management it is a decided advantage to have some fields on a farm without it. However, as a- means of building up fertility in a permanent pasture red clover has its uses, provided sufficient stock can be crowded on during the growing period to keep it in check. The heavy red clover growth will allow of livestock concentration and the tramping and 
manuring of large numbers of stock rapidly improve the pasture swara.

The grass and clover seed "mixture should be sown with 3 cwt. of superphosphate and a further $3 \mathrm{cwt}$. should be applied within 4 months of sowing' and another 3 cwt. 12 months after sowing; thereafter the land should 'be dressed with 2 to 3 cwt. of superphosphate per annum. There are, however, indications that after one or two decades of dairying, potassic as well as phosphatic fertilizers may be necessary for topdressing.

\section{FARM MANAGEMENT}

Since cobalt became available to combat bushsickness, pumice land pastures may be used for dairying and lamb, mutton, and beef production, and the undeveloped pumice lands offer great scope for settlement in the immediate future. Experience has shown that during the 'second year of establishment permanent pastures on' pumice land will produce in the vicinity of 100 th of butterfat per acre, rising to 150 th and over as the kerd and land improve. The winters in the inland, areas are fairly severe and adequate provision must be', made for winter feeding. Pumice land grows excellent root crops and these may be supplemented with hay and silage cut from -permanent and temporary pastures, or' total reliance may be placed on hay and silage for supplementary feeding.

Cobalt, certified grass and clover seeds, and superphosphate have made possible the large-scale development of spumice country, and after viewing the land development areas I am sure you will agree that "pumice land, is kindly stuff . . . . and may be termed natural grass country." 